\title{
SLCO1B3 Gene
}

National Cancer Institute

\section{Source}

National Cancer Institute. SLCO1B3 Gene. NCI Thesaurus. Code C106617.

This gene plays a role in both the sodium-independent uptake of endogenous and xenobiotic compounds and the transport of bile acid and bilirubin. 